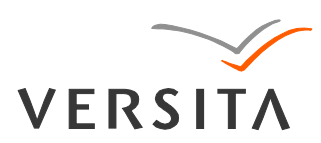

GEOCHRONOMETRIA 41(2) 2014: 121-128

DOI 10.2478/s13386-013-0150-5

Available online at

www.springerlink.com

\title{
RADIOCARBON AND DENDROCHRONOLOGICAL DATING OF SUB-FOSSIL OAKS FROM SMARHOŃ RIVERINE SEDIMENTS
}

\author{
ADOMAS VITAS ${ }^{1}$, JONAS MAŽEIKA ${ }^{2}$, RIMANTAS PETROŠIUS ${ }^{2}$ and RŪTILE் PUKIENÉ ${ }^{\mathbf{1}}$ \\ ${ }^{1}$ Group of Dendroclimatology and Radiometrics, Centre of Environmental Research, Faculty of Nature Sciences, Vytautas Magnus \\ University, Ž.E. Zilibero str. 6 LT-46324 Kaunas, Lithuania \\ ${ }^{2}$ Radioisotope Research Laboratory, Institute of Geology and Geography, Nature Research Centre, \\ T. Ševčenkos str. 13, LT-03223 Vilnius, Lithuania
}

Received 27 May 2013

Accepted 6 December 2013

\begin{abstract}
Sub-fossil oaks from Smarhoń in Belarus have been investigated and tree-ring chronologies were assembled. According to radiocarbon dating, the oldest oak grew from 5782-5612 cal BC and the youngest from 1575-1747 cal AD. Radiocarbon and dendrochronological dating of 97 samples, four single series, 10 mean curves (containing 2-9 series) and three chronologies (10-25 series) were constructed. The longest chronology (No. 16), covering 549 years, was absolutely dated against various oak chronologies of Polish/Baltic origin to AD 778-1326. Germination and dying-off phases were assessed from the three best replicated chronologies. A spectral analysis of the chronologies provided cycles of variable length, on average of 25 years.
\end{abstract}

Keywords: sub-fossil oak, tree-ring widths, dendrochronology, radiocarbon, Smarhoń.

\section{INTRODUCTION}

Long-term oak (Quercus spp.) chronologies have been successfully applied for reconstructing environmental, hydrological and climatic conditions during the Holocene (Briffa and Matthews, 2002; Kalicki and Krąpiec, 1995; Spurk et al., 2002) as well as for radiocarbon calibration (Spurk et al., 1998). Sub-fossil wood excavated from riverine sediments has been one of the sources for constructing millennia-long oak chronologies in Europe. Such long-term oak chronologies have, for example, been developed for the Czech Republic (Kolar et al., 2009), Germany (Delorme, 1977); Ireland (Pilcher et al., 1984), Poland (Starkel and Krąpiec, 1995), Romania (DumitriuTataranu and Popescu, 1988) and other countries.

Corresponding author: A. Vitas

e-mail: a.vitas@gmf.vdu.lt
Sub-fossil oak wood in the Baltic States and Belarus is not yet adequately explored by dendrochronology (Pukiené, 2003; Vitas and Zunde, 2007). The majority of studies until now were limited by a small number of samples available (Vitas and Zunde, 2007).

Sub-fossil oaks excavated in the vicinity of Smarhon (Belarus) have been in the attention of scientists since the 1960s (Bitvinskas et al., 1972). Initial difficulties were caused by the lack of sufficiently precise radiocarbon dates and missing oak reference chronologies in the Baltic region (Bitvinskas et al., 1978a; 1978b; Bitvinskas, 1984).

The aim of this study is to explore the tree-ring series from sub-fossil oaks found in Smarhoń riverine deposits, to construct precisely dated chronologies documenting forest history in Lithuania during the Holocene, and to assess its potential as reference chronologies for Baltic oak timber. 


\section{METHODS}

\section{Field description and materials}

The research site (Smarhoń in Belarusian language, Smurgainys in Lithuanian) is located in the Grodno district in Belarus, $85 \mathrm{~km}$ south-east from the Lithuanian capital Vilnius and $52 \mathrm{~km}$ from the present state border of Lithuania (Fig. 1). Trunks of oak were excavated in the 1960s and 1970s during the exploitation of a gravel pit, located on the bank of the river Viliya (Neris), approximately $10 \mathrm{~km}$ to the east from the Smarhon town (Bitvinskas, 1978a; 1978b; 1984). The trunks buried under the gravel by the meandering river (Bitvinskas, 1974; 1978a) were excavated in huge amounts. Besides oak, wood of conifers was also identified but not collected.

The trunks were of variable size; some samples exceeded $1.5 \mathrm{~m}$ in diameter. They were found at $3-8 \mathrm{~m}$ depth and usually pulled out with remains of the stump and big roots (Fig. 2). The wood was well preserved under the gravel (Bitvinskas et al., 1972). The majority of cross-sections were collected in 1968, 1969, 1970, 1971,

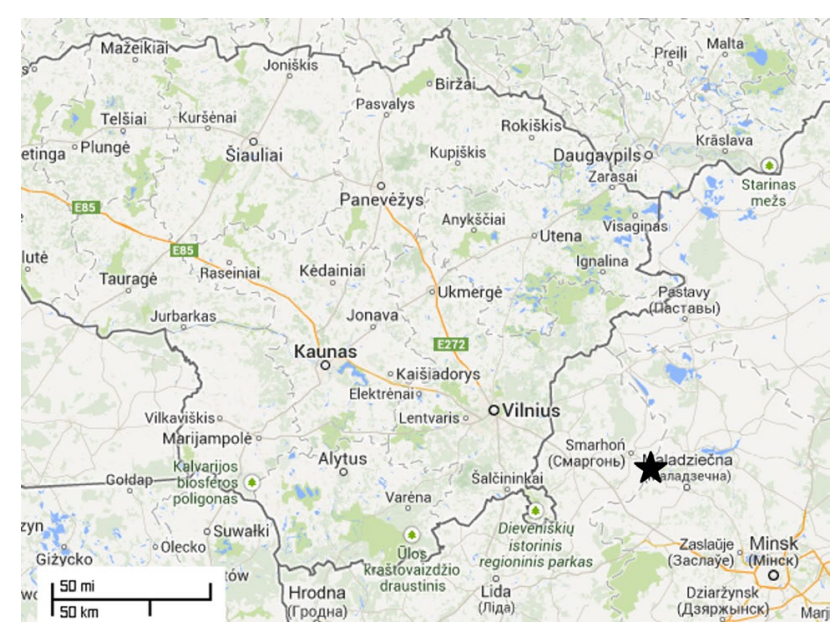

Fig. 1. Research site in Belarus produced by Google maps.

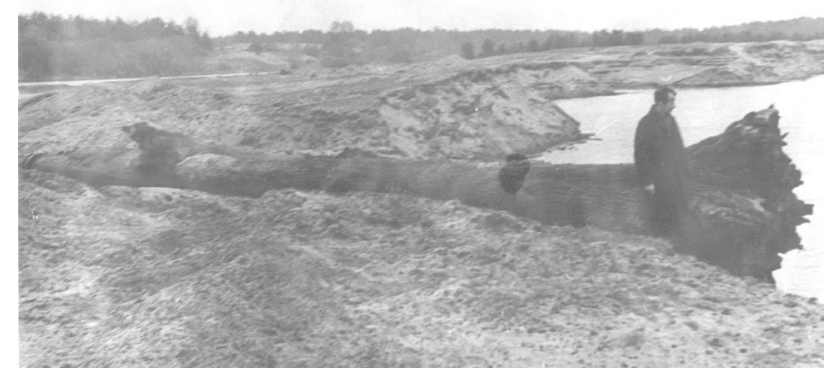

Fig. 2. Oak trunk at Smarhon site investigated by workers of the Dendrochronological Laboratory; photo from the repository of the Group of Dendroclimatology and Radiometrics, Kaunas. and 1972; in total 129 samples were obtained. At present, 109 cross-sections are being stored in the repository of the Laboratory. The wood of twenty samples was completely used for earlier isotope studies.

\section{Methods}

In the Soviet period, part of the samples was dated in several radiocarbon laboratories by using mainly selfmade radiation counters: University of Tbilisi, Ural Pedagogical Institute and Institute of Botany in Vilnius (Bitvinskas et al., 1978a; 1978b; Bitvinskas, 1984, see also list of ${ }^{14} \mathrm{C}$ dates in the Appendix). At present, the majority of samples has been dated by the Group of Dendroclimatology and Radiometrics, Environmental Research Centre, Faculty of Nature Sciences, Vytautas Magnus University (Kaunas) and by the Radioisotope Research Laboratory, Institute of Geology and Geography, Nature Research Centre (Vilnius) by using commercially produced equipment. The ${ }^{14} \mathrm{C}$ dates were calibrated to calendar years (Appendix) by using the OxCal 4.2 program (Bronk Ramsey et al., 2010) with the IntCal13 calibration curve (Reimer et al., 2013).

The quality of the radiocarbon dates was checked by applying the following criteria: (i) the most recent date was assumed to be more precise than the earlier ones if the sample was dated several times; (ii) if the sample was dated for more than three times, dates varying for more than 200 years were rejected; (iii) the dates were checked again after dendrochronological dates became available. The middle ring in the dated wood section was established and dates varying more than 100 years from the average were removed. The following principles have proved to be adequate when the chronology No. 16 was later absolutely dated with a 32-year bias in comparison to the average radiocarbon date.

The tree-ring widths of the sub-fossil oaks were measured using a Lintab tree-ring measuring table and Tsap computer program (F. Rinn Engineering Office and Distribution, Heidelberg). The tree-ring-width series were synchronized by visual comparison (Eckstein, 1987) of the ring-width graphs and statistically by calculating the coefficients of similarity "Gleichläufigkeit", correlation coefficients and t-values (Eckstein and Bauch, 1969; Baillie and Pilcher, 1973). Common statistics used in dendrochronology were calculated, such as mean treering widths, similarity between the series, and mean sensitivity. Several European oak chronologies were used for the absolute dating of the floating chronology No. 16: East Pomerania, Poland (T. Wazny), Vilquro1, Lithuania (Pukienè, 2002), Baltic1 (Hillam and Tyers, 1995). The germination and die-off phases were assessed from three chronologies: No 4 (4191-3830 cal BC), No 10 (1137$716 \mathrm{cal} \mathrm{BC}$ ) and No 16 (AD 778-1326). Each chronology is compiled from at least 10 individual series (Table 1).

Cycles expressed in the tree-ring chronologies were determined by using a single series Fourier (spectral) analysis (Statistica 6.0, StatSoft Inc.). 
Event years were assessed from the absolutely dated chronology No. 16. The calculation using program Weiser (Gonzales, 2001) was performed for the period AD 872-1266 which was covered by at least three treering series. The $\mathrm{Zi}$ index value (Schweingruber et al. 1990) was set to $\leq-0.75$ (narrow rings) and $\geq 0.75$ (wide rings) and the threshold for pointer years was set to $80 \%$. The higher values for both indicators were applied because of a comparatively small number of trees (3-19). The climatic anomalies from AD 1000-1266 were assessed from the compendium "The unusual natural phenomena in the territory of Lithuania in the $11^{\text {th }}-20^{\text {th }}$ centuries" by Bukantis (1998) which covers all chronicles available.

\section{RESULTS}

\section{Dating and chronology building}

The number of data for our study was limited to 122 cross-sections. The tree-ring widths from 109 samples were measured. In addition, we used old measurements of 13 samples which were no longer available. Samples containing less than 80 rings (eight samples) or measurement with a lower measuring accuracy ( 0.05 instead of $0.01 \mathrm{~mm}$ ), and lack of information about measuring direction of earlier measurements (five samples) were excluded from further analysis. Moreover, 12 samples failed to cross-date with any other samples. Hence, 97 samples were included into the mean curves and chronologies.

In total, 143 radiocarbon dates for 79 samples (18 samples were not dated) were available (Appendix), i.e.

Table 1. Radiocarbon dating of floating series and chronologies; mean radiocarbon dates were based on reliably dated samples.

\begin{tabular}{|c|c|c|c|c|c|c|}
\hline 운 & 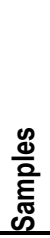 & 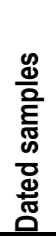 & 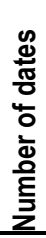 & 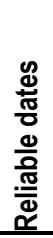 & 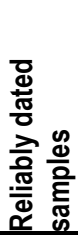 & 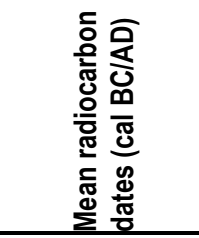 \\
\hline 1 & 1 & 1 & 2 & 2 & 1 & $5782-5612$ BC \\
\hline 2 & 1 & 1 & 2 & 2 & 1 & $5546-5325 \mathrm{BC}$ \\
\hline 3 & 2 & 2 & 3 & 3 & 2 & 4669-4496 BC \\
\hline 4 & 14 & 12 & 22 & 20 & 11 & $4191-3830$ BC \\
\hline 5 & 2 & 2 & 4 & 4 & 2 & 3542-3263 BC \\
\hline 6 & 3 & 2 & 2 & 2 & 2 & $3428-3246$ BC \\
\hline 7 & 2 & 2 & 3 & 1 & 1 & $3254-3088$ BC \\
\hline 8 & 3 & 2 & 6 & 4 & 2 & 3097-2987 BC \\
\hline 9 & 1 & 1 & 2 & 2 & 1 & $1900-1817$ BC \\
\hline 10 & 10 & 7 & 8 & 6 & 6 & $1137-716 \mathrm{BC}$ \\
\hline 11 & 2 & 2 & 3 & 1 & 1 & 595-382 BC \\
\hline 12 & 9 & 8 & 24 & 15 & 7 & 320 BC-AD 162 \\
\hline 13 & 9 & 6 & 7 & 6 & 5 & AD 190-421 \\
\hline 14 & 8 & 7 & 10 & 8 & 6 & AD 246-556 \\
\hline 15 & 4 & 4 & 10 & 7 & 4 & AD 547-718 \\
\hline 16 & 25 & 18 & 33 & 29 & 17 & AD 810-1358 \\
\hline 17 & 1 & 1 & 2 & 2 & 1 & AD 1575-1747 \\
\hline
\end{tabular}

nearly two dates per sample (Table 1). According to cross-dating and radiocarbon dating, these 97 samples were arranged into 17 groups containing one to 25 series each (Fig. 3). The majority of samples were dated at least twice and some with four to six repetitions (Appendix). The percentage of reliable dates reaches $60-80 \%$. The oldest tree grew approximately from $5782-5612$ cal BC and the youngest from 1575-1747 cal AD (Table 1).

The longest gap, according to radiocarbon dates, exists between 2987 and 1137 cal BC; a short sample grew around 1900-1817 cal BC (Table 1, Fig. 3). The youngest sample (No. 17) was dated twice in two laboratories and the dates are 1653-1954 and 1524-1954 cal AD within $95.4 \%$ probability.

Tree-ring series are characterized by a high mean similarity, ranging from $0.50-0.70$ for the majority of the samples in the chronologies (Table 2). A medium sensitivity (0.21-0.25) is typical of the majority of chronologies. The longest chronology, spanning 549 years, was radiocarbon-dated to 810-1358 cal AD.

A very high agreement between some samples ( 30 out of 97) indicates the possibility of duplicates in the collection, i.e. several samples were taken from the same trunk. The duplicates are characterized by correlation values from $0.70-0.94$, "Gleichläufigkeit" from $72-94 \%$ and $\mathrm{t}$-values from $9.6-34.8$.

The chronology No. 16 was absolute dated against East Pomerania, Vilcuro1 and Baltic1 reference chronologies to AD 778-1326 ( $\mathrm{t}=5.4,7.0$ and 8.4, respectively) and was shifted by 32 years backwards in time (Table 3, Fig. 4).

Table 2. Tree-ring characteristics of floating mean curves; similarity was calculated for mean curves and chronologies, comprised from at least two series; N/A - not available.

\begin{tabular}{|c|c|c|c|c|}
\hline 은 & 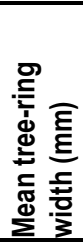 & 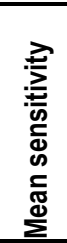 & 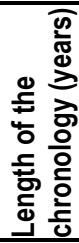 & 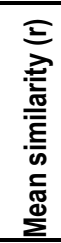 \\
\hline 1 & 1.08 & 0.25 & 171 & $\mathrm{~N} / \mathrm{A}$ \\
\hline 2 & 1.19 & 0.23 & 222 & $\mathrm{~N} / \mathrm{A}$ \\
\hline 3 & 1.65 & 0.24 & 174 & 0.79 \\
\hline 4 & 1.82 & 0.23 & 362 & 0.60 \\
\hline 5 & 1.18 & 0.26 & 280 & 0.34 \\
\hline 6 & 1.39 & 0.18 & 183 & 0.55 \\
\hline 7 & 1.82 & 0.20 & 167 & 0.63 \\
\hline 8 & 2.23 & 0.21 & 111 & 0.58 \\
\hline 9 & 2.12 & 0.24 & 84 & $\mathrm{~N} / \mathrm{A}$ \\
\hline 10 & 1.18 & 0.21 & 422 & 0.68 \\
\hline 11 & 1.58 & 0.24 & 214 & 0.52 \\
\hline 12 & 1.81 & 0.23 & 483 & 0.66 \\
\hline 13 & 1.74 & 0.24 & 232 & 0.66 \\
\hline 14 & 1.59 & 0.27 & 311 & 0.57 \\
\hline 15 & 1.77 & 0.27 & 172 & 0.67 \\
\hline 16 & 1.49 & 0.21 & 549 & 0.68 \\
\hline 17 & 1.68 & 0.24 & 173 & $\mathrm{~N} / \mathrm{A}$ \\
\hline
\end{tabular}




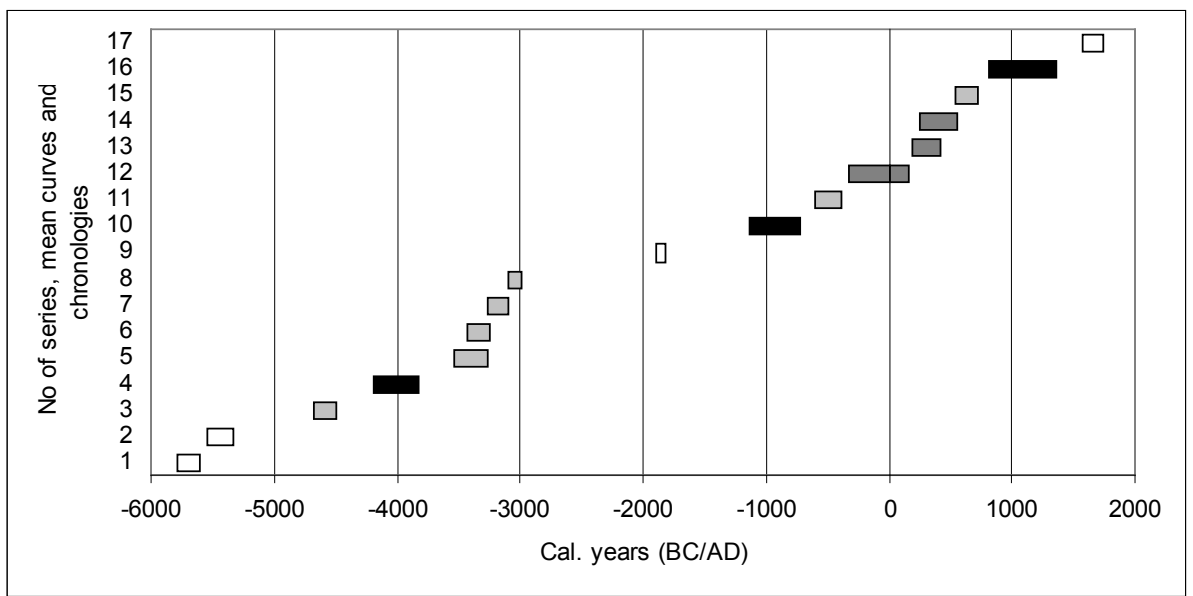

Fig. 3. Floating individual tree-ring width series, mean curves and chronologies; white bars indicate individual series, light grey - mean curves from 2-5 and dark grey - 5-10 samples, black - chronologies of at least 10 samples.

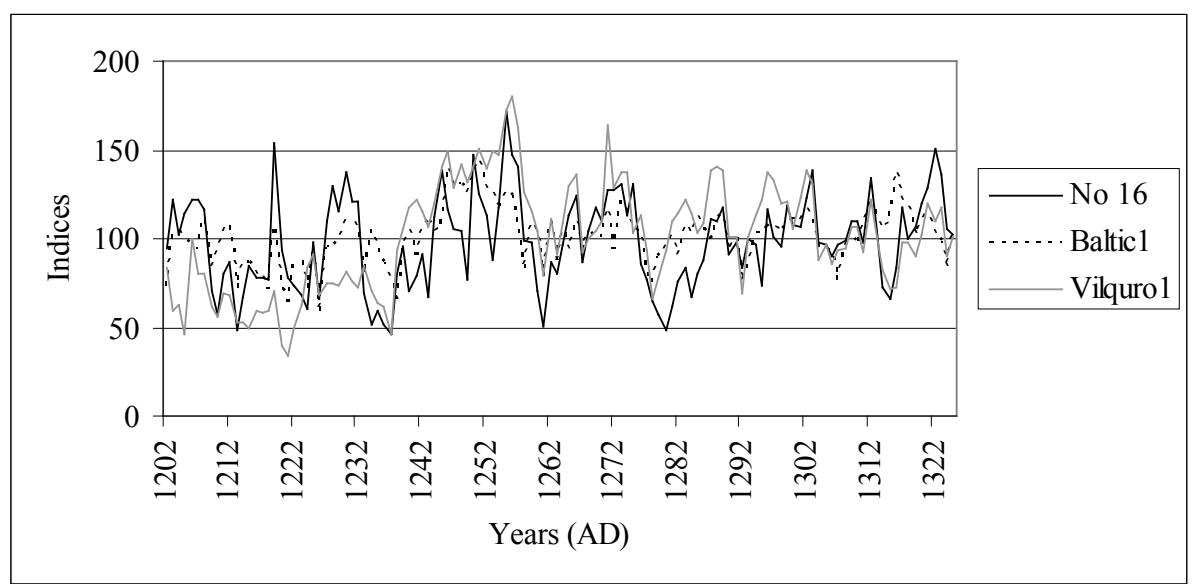

Fig. 4. Tree-ring width pattern of chronologies No. 16, Vilquro 1 and Baltic 1 from 1202-1326 AD.

Table 3. Similarity of the chronology No. 16 (AD 778-1326) against Vilquro1, Pomerania and Baltic1 chronologies; OVL - overlap (years), GLK-coefficient of similarity, $R$-coefficient of correlation, $T V-t$-test.

\begin{tabular}{|c|c|c|}
\hline Name & Span (AD) & OVL GLK R \\
\hline $\begin{array}{l}\text { Pomerania, Poland } \\
\text { (T. Wazny) }\end{array}$ & $778-1326$ & $\begin{array}{llll}549 & 61 & 0.23 & 5\end{array}$ \\
\hline $\begin{array}{l}\text { Vilquro1, Vilnius, Lithuania } \\
\text { (R. Pukiené) }\end{array}$ & $1202-1326$ & $\begin{array}{llll}125 & 67 & 0.54 & 7\end{array}$ \\
\hline $\begin{array}{l}\text { Baltic1 } \\
\text { (J. Hillam, I. Tyers) }\end{array}$ & $1156-1326$ & $\begin{array}{llll}171 & 65 & 0.54 & 8\end{array}$ \\
\hline
\end{tabular}

\section{Germination and die-off (GDO) phases in the chro- nologies}

The replication (number of trees through time) of each chronology (Fig. 5) was divided into three phases: a) intense germination $(\mathrm{G})$, the number of trees is increasing because of favourable environmental conditions, b) plateau phase $(\mathrm{P})$, the number of samples is stable, trees have reached their mature age and new trees have not germi- nated because of worsened growth conditions, c) dyingoff (DO) phase, dying of trees with different intensity due to a deterioration of environmental conditions.

The germination in the oldest chronology (No. 4) lasted from 4191-4084 cal BC and was followed by a short plateau phase from 4083-3960 cal BC (Fig. 5). The DO was prolonged in comparison to chronologies No. 10 and 14 and lasted for 129 years (from 3959-3830 cal BC). The chronology No. 10 has reached a plateau phase already after 75 years (1137-1062 cal BC); this phase has lasted from 1061-849 cal BC. The trees have died from $848-716 \mathrm{cal} \mathrm{BC}$. The germination of trees included in the chronology No. 14 lasted from AD 778-970. The plateau phase was short (AD 971-1031), and then a rapid DO phase took place (AD 1032-1089). Shortly after, a short germination with a plateau phase has repeated from $\mathrm{AD}$ 1102-1157. Favourable germination conditions occurred from AD 1170-1244 BC. The last extremely rapid DO event took place from AD 1245-1270; during this 25 -year period, the number of trees has decreased from seven to one (Fig. 5). 


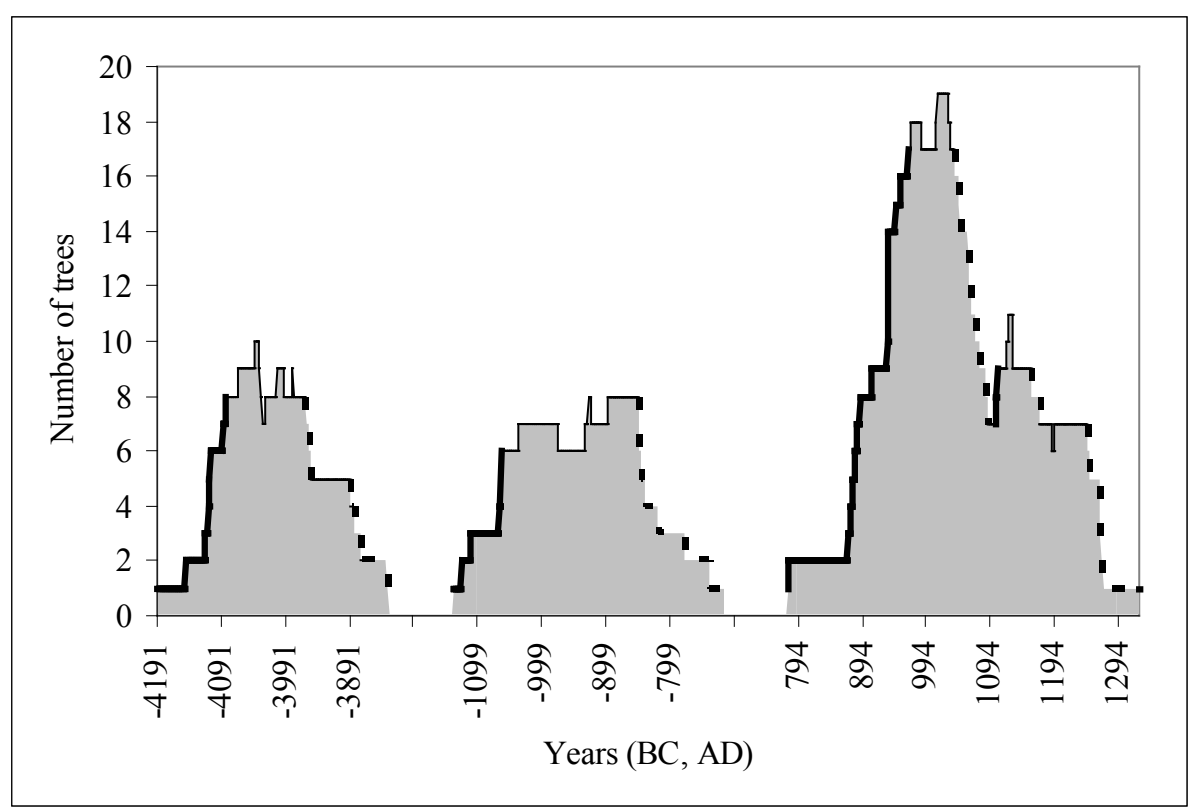

Fig. 5. Replication (number of trees) of Smarhon oak chronologies No. 4, 10 and 16. Regeneration phase is shown in solid line, plateau phase - thin line and declining - solid dotted line.

\section{Spectral density in oak chronologies}

Ten major and statistically significant cyclical components in the oak chronologies were identified. The cycles range from 3 to 241 years and the average length from 11 to 56 years. Hence, the length of cycles is variable for individual chronologies. Similar cyclical components in two or three adjacent chronologies indicate that the environmental conditions reflected in the changes of tree-ring widths repeated with the same frequency for longer time spans. For the oldest chronologies (5782$5612,5546-5325$ and $4669-4496 \mathrm{cal} \mathrm{BC}$ ), the average length of the cycles varied from 12-23 years. In 4191$3830,3542-3263,3428-3246$ and 3254-3088 cal BC the length has increased to 23-39 years. Shorter 11-15-year cycles were characteristic for 3097-2987 and 1900-1817 cal BC, and then increased to $30-56$ years in $1137-716$ and 595-382 cal BC (Table 4). The following decrease in cycle length was a long-lasting event $(320 \mathrm{cal} \mathrm{BC}-162$ cal AD and 190-421 cal AD). This was followed by the increased length of cycles to 27-38 years in the last four chronologies (246-556 cal AD, 547-718 cal AD, AD 778-1326 and 1575-1747 cal AD).

\section{Event years}

There were 24 negative and 20 positive event years from AD 871-1266 (Table 5). Because the information on climatic anomalies before AD 1000 is incomplete, the climatic evidences were assessed only from AD 10001266.

The occurrence of negative event years mostly coincided with periods of cold winters, e.g. from 1045-1047 and in 1125. In 1213, summer drought was responsible for the narrow tree-ring width. The growth increases (positive event years) could not be related to climatic phenomena because the chronicles usually highlight events causing negative impacts on human health or agricultural harvests and do not point on favourable climatic conditions.

\section{DISCUSSION}

The earlier radiocarbon age determinations of subfossil oaks already indicated that the dates are dispersed over the whole Holocene (Bitvinskas et al., 1978b; Bitvinskas, 1984). Our investigation confirmed that the accumulation of oaks in the Viliya river valley was not a constant process, and that meandering was common for the river in the vicinity of Smarhon. Furthermore, an

Table 4. Major statistically significant cycles in the oak chronologies.

\begin{tabular}{ccl}
\hline No & Period (BC/AD) & Cyclical components (years) \\
\hline $\mathbf{1}$ & $5782-5612 \mathrm{cal} \mathrm{BC}$ & $3,11,12,17,21,24,42,57,85,170$ \\
$\mathbf{2}$ & $5546-5325 \mathrm{cal} \mathrm{BC}$ & $8,9,12,12,13,16,22,25,32,56$ \\
$\mathbf{3}$ & $4669-4496 \mathrm{cal} \mathrm{BC}$ & $4,4,5,8,10,13,17,35,44,58$ \\
$\mathbf{4}$ & $4191-3830 \mathrm{cal} \mathrm{BC}$ & $15,17,26,28,30,33,40,72,90,121$ \\
$\mathbf{5}$ & $3542-3263 \mathrm{cal} \mathrm{BC}$ & $8,11,19,26,31,47,56,70,93,140$ \\
$\mathbf{6}$ & $3428-3246 \mathrm{cal} \mathrm{BC}$ & $9,12,13,18,20,26,30,36,46,182$ \\
$\mathbf{7}$ & $3254-3088 \mathrm{cal} \mathrm{BC}$ & $6,11,15,17,24,28,33,55,83,166$ \\
$\mathbf{8}$ & $3097-2987 \mathrm{cal} \mathrm{BC}$ & $4,6,7,8,12,18,22,37,55,110$ \\
$\mathbf{9}$ & $1900-1817 \mathrm{cal} \mathrm{BC}$ & $6,6,7,8,10,12,17,28,42,84$ \\
$\mathbf{1 0}$ & $1137-716 \mathrm{cal} \mathrm{BC}$ & $7,14,15,35,42,70,84,106,141,211$ \\
11 & $595-382 \mathrm{cal} \mathrm{BC}$ & $9,13,13,15,24,36,43,54,71,214$ \\
$\mathbf{1 2}$ & $320 \mathrm{cal} \mathrm{BC}-\mathrm{cal} \mathrm{AD} \mathrm{162} 5,10,10,12,17,18,27,69,161,241$ \\
$\mathbf{1 3}$ & cal AD 190-421 & $5,8,8,12,16,23,26,58,77,232$ \\
14 & cal AD 246-556 & $9,17,18,26,31,44,52,62,78,103$ \\
$\mathbf{1 5}$ & cal AD 547-718 & $4,5,8,11,14,29,43,57,86,172$ \\
16 & AD 778-1326 & $11,15,17,24,25,39,42,55,68,91$ \\
17 & cal AD 1575-1747 & $12,14,16,25,29,34,43,57,86,172$ \\
\hline
\end{tabular}


Table 5. Event years in the chronology No. 16 (AD 871-1266).

\begin{tabular}{|c|c|c|c|c|c|}
\hline $\begin{array}{l}\text { Event } \\
\text { year }\end{array}$ & $\begin{array}{l}\text { No of } \\
\text { trees }\end{array}$ & $\begin{array}{c}\text { Percentage of } \\
\text { trees }(\%)\end{array}$ & $\begin{array}{l}\text { Event } \\
\text { year }\end{array}$ & $\begin{array}{l}\text { No of } \\
\text { trees }\end{array}$ & $\begin{array}{c}\text { Percentage of } \\
\text { trees }(\%)\end{array}$ \\
\hline 875 & 3 & 100 & 1051 & 14 & 93 \\
\hline 894 & 8 & 88 & 1066 & 11 & 100 \\
\hline 900 & 8 & 100 & 1068 & 11 & 82 \\
\hline 902 & 8 & 88 & 1095 & 7 & 100 \\
\hline 911 & 9 & 100 & 1107 & 9 & 89 \\
\hline 912 & 9 & 89 & 1116 & 9 & 89 \\
\hline 918 & 9 & 100 & 1122 & 10 & 90 \\
\hline 919 & 9 & 100 & 1125 & 11 & 100 \\
\hline 922 & 9 & 100 & 1136 & 9 & 100 \\
\hline 928 & 9 & 100 & 1147 & 9 & 89 \\
\hline 930 & 9 & 89 & 1150 & 9 & 89 \\
\hline 931 & 9 & 100 & 1174 & 7 & 86 \\
\hline 939 & 14 & 100 & 1178 & 7 & 100 \\
\hline 960 & 16 & 81 & 1192 & 6 & 100 \\
\hline 962 & 16 & 88 & 1201 & 7 & 86 \\
\hline 963 & 16 & 81 & 1213 & 7 & 100 \\
\hline 965 & 17 & 100 & 1219 & 7 & 100 \\
\hline 980 & 18 & 94 & 1226 & 7 & 86 \\
\hline 984 & 18 & 83 & 1243 & 7 & 86 \\
\hline 999 & 17 & 100 & 1245 & 6 & 100 \\
\hline 1026 & 19 & 90 & 1250 & 5 & 100 \\
\hline 1046 & 14 & 93 & 1253 & 5 & 100 \\
\hline
\end{tabular}

erosion of the eastern bank was observed in the 1970s by Bitvinskas and Kairaitis (1975). Cross-dating of the samples has indicated several periods during the Holocene with much higher numbers of accumulated oak trunks, e.g. in 4191-3830 cal BC, 1137-716 cal BC and 7781326 AD. Becker (1972) has suggested a catastrophic flood event in the Subatlantic period. Later, channel migration (Florek, 1984) and lateral erosion (Kalicki, 1991; Spurk et al., 2002) were proposed, supported by the intensified river activity (Becker, 1982; Kalicki, 2006) and water discharge (Spurk et al., 2002) during wet periods (Krąpiec 1994). The human activity during the last 2000 years in the Vistula and Main river valleys has also been acknowledged (Krąpiec, 1994; Spurk et al., 2002). Spurk et al. (2002) observed deposition anomalies triggered by a positive North Atlantic Oscillation (NAO) phase.

\section{Neolithic period}

The tree-ring series from 5546-5325 and 4669-4496 cal BC coincide with a gravel accumulation phase in Germany from 5500-4500 BC (Spurk et al., 1998). The period covered by the chronology No. 4 (4191-3830 cal $\mathrm{BC}$ ) was characterized by a low deposition rate of oaks in Germany around 4100 BC. Wet conditions in Europe and greater depositions of river oaks in England are evidence for a higher runoff. The Greenland temperatures inferred from ice-cores show cooler conditions (Spurk et al., 2002). This climate anomaly was caused by the Bond cycle which is associated with reduced thermohaline circulation and cooled the climate over Europe (Boecker et al., 1985). However, chronology No. 4 based on 20 radiocarbon dates (Table 1) has shown that oaks at Smarhoń have germinated from 4191-4084 cal BC, while the DO phase was prolonged and lasted for 129 years (from 3959-3830 cal BC). Kalicki (2006) have documented an increased Vistula river activity from 6600 $6000 \mathrm{BP}$.

The oaks dated to 3428-3246, 3254-3088 and 30972987 cal BC correspond to the floating chronologies derived for the Vistula valley by Krapiec (1994), dated to 3385-3250 cal BC and 3168-2980 cal BC. An accumulation phase in the rivers of Belarus was recorded in 5050 5700 BP (Kalicki, 2006). The oak deposition anomalies in Germany in 2700, 2300 and 1700 BC (Spurk et al., 2002) match with the longest gap in our dataset between 3060 and $1100 \mathrm{cal} \mathrm{BC}$.

\section{Bronze Age}

The chronology No. 10 (1137-716 cal BC), composed of 10 trees, represents cooler and wetter climate in Europe around $800 \mathrm{BC}$ (van Geel et al., 1998). Chronology from the Odra valley (1795-612 BC) in Poland was also compiled for this period (Krapiec, 2001). The increased river activity near Cracow was documented from 35003000 BP (Kalicki, 2006).

\section{Iron Age}

Several local oak chronologies have been compiled in Poland: Vistula 1 (174 BC-304 AD), Standard 1 (261823 AD), Wielkopolska (449-1994 AD), Cracovia 1 (729-1141 AD), Lower Silesia (780-1994 AD), Małopolska (910-1977 AD) and Vistula 2 (1100-1529 AD) (Krąpiec, 1992; 1998; Starkel and Krąpiec, 1995). According to Krapiec (1994), the accumulation of oaks in the Vistula valley took place from $375-325$ BC, AD 425 575, AD 900-1150 and AD 1200-1325. At the BraniceStryjów site, oaks were accumulated from $50 \mathrm{BC}-\mathrm{AD}$ 175, AD 950-1028 and AD 1210-1493 (Krąpiec, 1992). An intensified meandering activity was observed at the Kędzierz and Kujawy sites, Poland, from AD 408-540 and AD 440-560, respectively (Starkel and Krąpiec, 1995). This period is covered by one mean curve (No. 11). The climate in Germany between $300 \mathrm{BC}$ and $\mathrm{AD}$ 950 was wetter. Therefore, accumulation of gravel was recorded from AD 400-1000 (Spurk et al., 2002). This coincides with major dying phases of oaks in Germany in 300 and $100 \mathrm{BC}$ (Delorme et al., 1983). The Iron Age is represented by several well-replicated mean curves (No. $12,13,14)$ and by chronology No. 16, which coincides with the accumulation phases documented in rivers of Central Europe from 2200-1800 BP and around 1000 BP (Kalicki, 2006).

According to Krapiec (1994), the accumulation of oaks in the Vistula took place until AD 1550. Hence, sample No. 17 dated to $1575-1747$ cal AD, taking into account a possible dating bias of \pm 100 years, might be 
derived from an accumulation period, recorded for the Vistula river.

During higher oak accumulation phases at Smarhoń, longer cyclical components, 32 and 23-years were identified in the tree-ring patterns (Tables 1 and 4). Longer cycles in tree-ring series are usually related to wet growing conditions as shown by Stasytyte et al. (2005) and Vitas $(2009,2010)$. This is in agreement with findings in Europe indicating wetter conditions and a higher river runoff (van Geel et al., 1998; Krąpiec, 1994; Spurk et al., 2002; Starkel and Krapiec, 1995) during periods of high oak accumulation rates at Smarhon.

\section{CONCLUSIONS}

Our study was limited by the small number of samples, and by missing data on their finding depth, soil type and position to the river channel. This fact did not allow answering questions related to the river meandering activity during different periods of the Holocene. However, the chronologies, especially the absolutely dated chronology No. 16, are an important contribution to oak dendrochronology in the Baltic region and are valuable for the dating of oak timber over the Baltic territory or imported timber from the Baltic region.

Our investigation has demonstrated that sub-fossil oaks at Smarhon grew at least from $5782 \mathrm{cal} B C$ to $\mathrm{AD}$ 1326. The high deposition rate of oak trunks in 41913830 and $1137-716$ cal BC, 320 cal BC-162 cal AD, 190-421 cal AD and 246-556 cal AD as well as AD $778-1326$ is closely related to an increased river runoff and wet periods in Europe. The oak chronology No. 16 was absolutely dated to AD 778-1326. This successful dating against several well-replicated chronologies indicates that climatic extremes triggering oak growth decrease or increase at Smarhon were in operation over vast territories of Eastern Europe.

\section{ACKNOWLEDGMENTS}

We are grateful to Eng. Algimantas Daukantas and all other co-workers of the Dendrochronological and Radioisotope Research laboratories for participating in the fieldwork and radiocarbon dating. This study is partly implemented in the Project CLIMPEAT, which is supported by a grant from Switzerland through the Swiss Contribution to the enlarged European Union (Grant Agreement CH-3393 ŠMM-01/05).

\section{APPENDIX}

The Table S1 - Results of the radiocarbon analyses used for dating the floating chronologies - is provided as Supplementary Material and is available in electronic version of this article at http://dx.doi.org/10.2478/s13386013-0150-5.

\section{REFERENCES}

Baillie MGL and Pilcher JR, 1973. A simple cross-dating program for tree-ring research. Tree-Ring Bulletin 33: 7-14.

Becker B, 1972. Möglichkeiten für den Aufbau einer absoluten Jahringchronologie des Postglazials anhand subfossiler Eichen aus Donauschottern (Possibility for the construction of a tree-ring chronology for the postglacial with subfossil oaks from gravel deposits in the Danube river). Berichte der Deutschen Botanischen Gesellschaft 85: 29-45 (in German).

Becker B, 1982. Dendrochronologie und Paläoökologie subfosiller Baumstämme aus Flussablagerungen: ein Beitrag zur nacheiszeitlichen Auenentwicklung im südlichen Mitteleuropa (Dendrochronology and paleoecology of subfossil tree trunks from fluvial sediments: postglacial development of riparian areas in south-central Europe). Mitteilungen der Kommision für Quartärforschung der österreichishen Akademie der Wissenschaften 5, $120 \mathrm{p}$ (in German).

Bitvinskas T, 1974. Dendroklimaticheskye issledovanye (Dendroclimatological investigations). Leningrad, Gidrometeoizdat, $172 \mathrm{p}$ (in Russian).

Bitvinskas T, 1978a. K voprosu o vozmozhnosti postroenye sverchdolgosrochnych dendroshkal v Yuznoi Pribaltike (On the question of the possibilities of construction of supra-long chronologies in the southern Baltic region). In: Bitvinskas T, ed., Environmental conditions and radial increment of trees. Lithuanian Institute of Botany, Kaunas, p. 45-51 (in Russian).

Bitvinskas T, 1978b. Sverchdolgosrochnyje dendroshkaly i perspektivy ich sozdanya (Supra-long chronologies and perspectives of construction). Dendroclimatological investigations in the USSR. Archangelsk, p. 15-16 (in Russian).

Bitvinskas T, 1984. Biologycheskye osnovy dendroklimatochronologicheskych issledovanyi (Bioecological background of dendroclimatochronological investigations). Doctor habil. Dissertation (biology). Institute of Ecology for Plants and Animals, Sverdlovsk, 395 p (in Russian).

Bitvinskas T, Dergachev V, Daukantas A, Liiva A, Suurman S and Šulija K, 1978a. Ispolzovanyje radiouglerodnogo metoda datirovanya $\mathrm{v}$ celiach cozdanya sverchdolgosrochnych dendroshkal (Application of radiocarbon dating method for construction of supra-long chronologies). In: Bitvinskas T, eds., Environmental conditions and radial increment of trees. Lithuanian Institute of Botany, Kaunas, p. 51-55 (in Russian).

Bitvinskas T, Dergachev V, Kairaitis J and Zakarka R, 1972. K voprosu o vozmozhnosti postrojenye sverchdolgosrochnych dendroshkal v Yuznoi Pribaltike (On question of the possibilities of construction of the supra-long chronologies in the southern Baltic region). In: Kocharov et al., eds., Proceedings of the $2^{\text {nd }}$ inter-union conference for dendrochronology and dendroclimatology "Dendroclimatochronology and radiocarbon". Kaunas, Lithuanian Institute of Botany, p. 69-75 (in Russian).

Bitvinskas T, Dergachev V, Kocharov G, Liiva A, Suurman S and Šulija K, 1978b. Ispolzovanye radiouglerodnogo metoda datirovanya $\mathrm{v}$ celiach cozdanya sverchdolgosrochnych dendroshkal v uslovyach Yuznoi Pribaltiki (Application of radiocarbon dating method for construction of supra-long chronologies in southern Baltic region). In: Kocharov G, eds., Proceeding of the $6^{\text {th }}$ interunion symposium "Astrophysical phenomena and radiocarbon". Tbilisi, University of Tbilisi, p. 185-192 (in Russian).

Bitvinskas $\mathrm{T}$ and Kairaitis J, 1975. Dinamika radialnogo prirosta dubovych nasazhdenyi Litovskoi SSR i ee sviaz s uslovyami sredy, klimatom, i solnechnoy aktivnostiu (Dynamics of the radial growth of oak stands in Lithuanian SSR and its relationships to environmental conditions, climate and solar activity). Bitvinskas T, ed., Symposium materials of XII-International Botanical Congress "Bioecological fundamentals of dendrochronology". Vilnius: Lithuanian Institute of Botany, p. 69-74 (in Russian).

Boecker WS, Peteet DM and Rind D, 1985. Does the ocean-atmosphere system have more than one stable mode of operation? Nature 315(6014): 21-26, DOI 10.1038/315021a0. 
Briffa KR and Matthews JA, 2002. Advance-10K: a European contribution towards a hemispheric dendroclimatology for the Holocene. The Holocene 12(6): 639-642, DOI 10.1191/0959683602hl576ed.

Bronk Ramsey C, Dee M, Lee S, Nakagawa T and Staff R, 2010. Developments in the calibration and modelling of radiocarbon dates. Radiocarbon 52(3): 953-961.

Bukantis A, 1998. Neịprasti gamtos reiškiniai Lietuvos žemèse XI-XX amžiuose (The unusual natural phenomena in the territory of Lithuania in the $11^{\text {th }}-20^{\text {th }}$ centuries). Vilnius, Geografijos institutas: $197 \mathrm{p}$ (in Lithuanian)

Delorme A, 1977. Construction of a post-glacial tree-ring chronology at the University of Göttingen, Federal Republic of Germany, based on sub-fossil oak trunks. Dendrochronology in Northern Europe. Abstracts of the Symposium. Oxford, Research Laboratory for Archaeology and History Art: 11.

Delorme A, Leuschner HH, Tüxen J and Höfle HC, 1983. Der subatlantische Torfeichen-Horizont 'Sieden', erneut belegt im Toten Moor am Steinhuder Meer (A further occurrence of the Subatlantic PeatOak "Sieden" horizon in the Totes Moor near the Steinhuder Meer, Lower Saxony). Telma 13: 33-51 (in German).

Dumitriu-Tataranu I and Popescu M, 1988. Investigarea dendrocronologica a unui trunchi subfosil de stejar (Dendrochronological investigation of a subfossil oak trunk ). Studii si Cercetari de Biologie, Seria Biol. Veget. 40(1): 29-40 (in Romanian).

Eckstein D, 1987. Measurement and dating procedures in dendrochronology. In: Kairiukštis L, Bednarz Z and Feliksik E, eds., Methods of dendrochronology. IIASA, Warsaw, 3: 35-44.

Eckstein D and Bauch J, 1969. Beitrag zur Rationalisierung eines dendrochronologischen Verfahrens und zur Analyse seiner Aussagesicherheit (Contribution to the rationalization of a dendrochronological procedure and analysis of its significance). Forstwissenschaftliches Centralblatt 88(4): 230-250 (in German).

Florek W, 1984. Niektóre problemy sedymentologiczne związane z budowa teras środkowo- i młodoholoceńskich dolnego Bobru (Some sedimentation problems of the terrace formation during Young and Middle Holocene of lower Bobr). Rocznik PTG 54: 34, 397-410 (in Polish).

Gonzales IG, 2001. Weiser: a computer program to identify event and pointer years in dendrochronological series. Dendrochronologia 19(2): 239-244.

Van Geel B, Van Der Plicht J, Kilian MR, Klaver ER, Kouwenberg JHM, Renssen H, Reynaud-Farrera I and Waterbolk HT, 1998. The sharp rise of $\Delta 14 \mathrm{C}$ ca. $800 \mathrm{cal} \mathrm{BC}$ : possible causes, related climatic teleconnections and the impact on human environments. Radiocarbon 40(1): 535-550.

Hillam J and Tyers I, 1995. Reliability and repeatability in dendrochronological analysis: tests using the Fletcher archive of panelpainting data. Archaeometry 37(2): 395-405, DOI 10.1111/j.14754754.1995.tb00752.x.

Kalicki T, 1991. The evolution of the Vistula river valley between Cracow and Niepolomice in late Vistulian and Holocene times. In: Starkel L, eds., Evolution of the Vistula river valley during the last 15000 years, part IV. Geographical Studies, Special Issue 6: 1137.

Kalicki T, 2006. Zapis zmian klimatu oraz działalności człoweka i ich rola w Holoceńskiej ewolucji dolin środkowoeuropejskich (Reflection of climatic changes and human activity and their role in the Holocene evolution of Central European valleys). Prace Geograficzne 204: 1-348.

Kalicki T and Krapiec M, 1995. Problems of dating alluvium using buried subfossil tree trunks: lessons from the "black oaks" of the Vistula Valley, Central Europe. The Holocene 5(2): 243-250, DOI $10.1177 / 095968369500500213$.

Kolar T, Rybnicek M and Premyslovska E, 2009. Dating and properties of subfossil oak wood. In: Levanic T, Gricar J, Hafner P, Kranjnc
R, Jagodic S, Gartner H, Heinrich I and Helle G, eds., Tree Rings in Archaeology, Climatology and Ecology, Volume 8. Proc. of the Dendrosymposium 2009. GFZ German Research Centre for Geosciences, Potsdam, Germany. Scientific Technical Report STR10/05: 136-144.

Krapiec M, 1992. Skale dendrochronologiczne póznego holocenu południowej i centralnej Polski (Late Holocene tree-ring chronologies of south and central Poland). Kwartalnik AGH-Geologia 18: 37-119 (in Polish).

Krapiec M, 1994. "Czarne dęby" - Dendrochronologia i fazy akumulacji pni w Dolinie Wisły ("Black oaks" - dendrochronology and phases of accumulation of trunks in the Vistula Valley). In: Starkel $\mathrm{L}$ and Prokop P, eds., Environmental changes of the Carpathians and subcarpathians basins 20: 57-68 (in Polish).

Krąpiec M, 1998. Oak dendrochronology of the Neoholocene in Poland. Folia Quaternaria 69: 5-134

Krąpiec M, 2001. Holocene dendrochronological standards for subfossil oaks from the area of Southern Poland. Studia Quaternaria 18: 47-63.

Pilcher JR, Baillie MGL, Schmidt B and Becker B, 1984. A 7272-year tree-ring chronology for Western Europe. Nature 312(5990): 150 152, DOI $10.1038 / 312150 \mathrm{a} 0$.

Pukienė R, 2002. Paprastojo ąžuolo metinio radialiojo prieaugio kaitos chronologija nuo 1208 iki 1408 metu (Oak annual radial growth chronology covering 1208-1408). Dendrologia Lithuaniae 6: 102107 (in Lithuanian).

Pukienè R, 2003. Sub-fossil oak timbers from the Mid Holocene as an evidence for Lithuanian forest history. Baltic Forestry 9(2): 71-75.

Reimer PJ, Bard E, Bayliss A, Beck JW, Blackwell PG, Bronk Ramsey C, Grootes PM, Guilderson TP, Haflidason H, Hajdas I, Hatte C, Heaton TJ, Hoffmann DL, Hogg AG, Hughen KA, Kaiser KF, Kromer B, Manning SW, Niu M, Reimer RW, Richards DA, Scott EM, Southon JR, Staff RA, Turney CSM and van der Plicht J, 2013. IntCal13 and Marine13 Radiocarbon Age Calibration Curves 0-50,000 Years cal BP. Radiocarbon 55(4): 1869-1887.

Schweingruber FH, Eckstein D, Serre-Bachet F and Bräker OU, 1990. Identification, presentation of event years and pointer years in dendrochronology. Dendrochronologia 8: 9-38.

Spurk M, Friedrich M, Hofmann J, Remmele S, Frenzel S, Frenzel B, Leuchner HH and Kromer B, 1998. Revisions and extensions of the Hohenheim oak and pine chronologies - new evidence about the timing of the Younger Dryas/Preboreal transition. Radiocarbon 40: $1107-1116$

Spurk M, Leuschner HH, Baillie MGL, Briffa KR and Friedrich M, 2002. Depositional frequency of German subfossil oaks: climatically and non-climatically induced fluctuations in the Holocene. The Holocene 12(6): 707-715, DOI 10.1191/0959683602h1583rp.

Starkel L and Krapiec M, 1995. Profile of the alluvia with "Black oaks" in Kędzierz on the Wisłoka River. Evolution of the Vistula river valley. Geographical Studies 8: 101-110.

Stasytytė I, Pakalnis R and Vitas A, 2005. Dendrochronological investigation on Scots pine timber extracted from Lake Stirniai, Northeastern Lithuania. Baltic Forestry 11(1): 46-53.

Vitas A, 2009. Dendrochronological analysis of subfossil Fraxinus and Quercus wood excavated from the Kegai mire in Lithuania. Baltic Forestry 15(1): 41-45.

Vitas A, 2010. Dendrochronological analysis of subfossil Fraxinus from the Middle and Late Holocene Period in Lithuania. Tree-Ring Research 66(2): 83-92.

Vitas A and Zunde M, 2007. Dendrochronological investigation on historical English oak (Quercus robur L.) in Lithuania and Latvia: problems and potential. In: Elferts D, Brumelis G, Gärtner H, Helle G and Schleser G, eds., TRACE: Tree Rings in Archaeology, Climatology and Ecology, Assoc. for Tree Ring Research. Potsdam, 6: 124-127. 